\title{
Repetition in the Work of a Samoan Christian Theologian: Or, What Does It Mean to Speak of the Perfect Pig of God?
}

\author{
Matt Tomlinson
}

Published in History and Anthropology, 2018, as part of the special issue "Different Repetitions," edited by Andreas Bandak and Simon Coleman

This is the final pre-publication draft; for the published version, see:

DOI: $\underline{10.1080 / 02757206.2018 .1532896}$

In this article I focus on repetition, and specifically replication, as a point of common interest between anthropology and theology. Replication is creative repetition, the uptake of circulating signs and texts and reexpression of them in new contexts. Interest in replication has long informed anthropological approaches to studying cultural diffusion, mimesis, and continuity and transformation: for well over a century, anthropologists have analyzed humans' passion for doing things that have been done before and evaluating actions in terms of their oldness or newness. As I will describe, interest in replication has also informed one Samoan theologian's understandings of "creation" and "salvation." 
The article is divided into four sections. In the first, I describe work in linguistic anthropology on repetition and replication. Next, I discuss anthropology's recent overtures toward engaging with theology as exemplified in the work of Joel Robbins, Simon Coleman, Derrick Lemons, and others who argue that such an interdisciplinary dialogue can lead to genuinely productive intellectual transformations regardless of religious commitment. In the

third and fourth sections, I analyze the writings of a Samoan Congregationalist theologian, Ama'amalele Tofaeono, which I read through an anthropological lens. First, I explore Tofaeono's work on the topic of repetition in creation, for which he draws on Samoan myth as well as the work of Jürgen Moltmann to argue that creation is fundamentally a continuous act. Next, I examine Tofaeono's work on repetition in salvation, focusing on his interpretation of Jesus as the Melanesian “pig of God." Repetition in Tofaeono's theology, as I read it, is a mechanism for the twinned tasks of remaking creation and apprehending the possibility of salvation.

My interest in his work does not stem from personal religious commitment, but rather from my interest in how humans think about the spiritual in terms of relationships of sameness and difference, oldness and newness. This article is meant as an initial engagement with these topics and an attempt to develop a newly productive dialogue between anthropology and theology. If I am repeating myself already, I take that to be a good sign.

\section{Repetition and Replication in Language}

Repetition can be an instructional technique, for example to get a language-learner to repeat the right words with the right pronunciation to lock them in the mind and loosen them on the tongue. Repetition can also be poetic. A Texas Pentecostal preacher who instructed his audience, "If you've got your hope in money, that's a dead hope. If you've got your hope in friends, that's a 
dead hope. If you've got your...hope in what government might do, that's a dead hope" (see Tomlinson 2014b:35-36) was using the repetition of parallel constructions to emphasize that everything is a dead hope except for the alternative he was about to offer, hope in Jesus.

Indeed, in a work titled "Repetition in Discourse," Barbara Johnstone (with a remarkable 42 coauthors), writes: "Repetition is a multifaceted phenomenon. Repetition can mean agreement or disagreement, joking or hostility, work or play. It can be both cohesive and disjunctive. The more something is repeated, the more people come to expect it to be repeated: repetition eventually becomes the less foregrounded option, and suddenly not repeating is foregrounded. Whenever we talk about repetition, we have to talk about its opposite number. You can do something new by repeating yourself, and you show that you are not doing anything new by repeating yourself" (Johnstone et al. 1994:19; see also Haeri 2013). The key point is not just that repetition is multifaceted, but that it can sometimes call attention to itself as a process, serving as a sign in its own right.

Repetition is a sign with both iconic and indexical properties. In one sense, repetition is primarily an iconic sequence, with later signs resembling earlier ones. But repetition, as a process, also indexically "points to" an association that is (or seems like) a natural connection. For example, the thing to which repetition points may be the content's heightened value: some content needs to be repeated because it is more important than the discourse that surrounds it. Or repetition can chain together past and future utterances, calling attention to the fact that transmission has been successful, that speakers have been heard and their words can be reproduced (Urban 1994). ${ }^{1}$

Greg Urban makes a useful distinction between repetition and replication, writing that "Repetitions occur within the unit of communication — within a myth or a song or a speech 
style - simultaneously, as that unit may itself be replicated over time. Repetition is internal to the communicative unit, replication external, involving the reproduction of the unit over time. But the former is linked to the latter. If something can be repeated internally, it can be replicated externally" (Urban 1994:146; see also Urban 1996b:245). In a later work, Urban defines replication without reference to internality or externality, calling it simply "the creation of a new thing that shares the abstract form of an older one" (Urban 2001:42; see also Urban 1986, 1991, 1996a). Urban is careful to note that semantic meaning can be replicated without replicating form, as in the case of translation, and that form can be replicated without the replication of semantic meaning, as when neophytes recite sacred texts in foreign languages they do not understand. A key point is that replication is an act of repetition across contexts. In replication, the "same" signs and texts are expressed anew, often through new speakers to new audiences in new fields of performance.

Patrick Eisenlohr and Robin Shoaps have also written about replication and contrasted it with other forms of entextualization, especially transposition, the repetition of a text in a way that indicates the text's original context and authorship. For example, Shoaps has analyzed the use of transposition by the American radio host Rush Limbaugh, who has been successful in presenting his political views as matters of "common sense" to his audience. He does so through strategies such as uttering imagined thoughts and dialogues and mimicking stereotypical ways of speaking linked to particular characters. Limbaugh attempts to draw his listeners into a universe where anyone who disagrees with him is (clearly!) an idiot or corrupt. A speaker like Limbaugh presents his opinions as mere reportage of external fact, pointing to a "somewhere else" well established in previous discourse (1999:407; see also Shoaps 2002). ${ }^{2}$ Urban, like Eisenlohr and Shoaps, is concerned to distinguish replication from its alternatives, but rather than focus on 
original contexts and authorship he focuses on processes of circulation. In doing so, he contrasts replication with dissemination, the latter defined as the physical movement that gives products access to publics (Urban 2001; see also Urban 1996a).

To illustrate these terms so that my later discussion makes sense, consider the example of how Bible verses "move" through the world. The Bible is disseminated globally. Within particular languages and versions, the book—as a unitary object, sealed between covers, containing over 31,000 verses in more than 750,000 words (in English) - moves from printer to warehouse to shop to purchaser. In my office in Canberra, Australia, I have four Bibles sitting on my bookshelves: an English-language New International Version given to me by an evangelical student when I attended college in New Jersey; a Fijian language version with a well-worn burgundy cover, which I bought at the Methodist bookshop in Suva, Fiji's capital city, in the late 1990s; a more recent purchase, Da Jesus Book, a version of the New Testament published by Wycliffe Bible Translators to reach speakers of Hawaiian Pidgin; and a Samoan language version, fresh and jet black, given to me by a Samoan Congregationalist minister studying at the Australian National University. Each of these books has traveled widely as I have packed, unpacked, and repacked them through the years. Millions of identical copies (in the case of the New International Version) and thousands of them (in the Fijian, Hawaiian Pidgin, and Samoan versions) have gone around the planet on their own journeys of dissemination.

Bibles are disseminated as units, then, but replicated in textual fragments, which is to say people take up particular verses, passages, and stories and retell them in many different public forms (Bielo 2009). To replicate the Bible in its entirety, one would need to follow the example of medieval monks who inscribed each volume painstakingly, word by word and page by page (inevitably changing the text a bit each time; Ehrman 2005). Almost no one does that anymore, 
but many people reproduce parts of the Bible by quoting and misquoting particular passages as they read them aloud in churches, discuss them in study sessions, yell them on street corners, and so forth. They also embody biblical narratives in dramatic performances such as Easter passion plays, replicating stories by enacting them. [Insert figure 1 here]

In the hopscotch of replication, signs are continually recontextualized, and the "same" thing — such as a particular Bible verse — comes to look different over time in its material and immaterial aspects, the forms it takes and the meanings those forms help configure. Some texts are seen and heard across many contexts, such as John 3:16. Conversely, some texts do not seem to get replicated often. There are always variations by speaker and congregation, of course. "We were high-church Anglicans, to whom the Book of Revelation has always been an embarrassment," writes Jonathan Raban. "My father, a priest, did not dwell in his sermons on the Mark of the Beast or the Scarlet Whore of Babylon. I called him up today to ask him if he had ever had reason to quote from Revelation in the course of his professional life. He huffed and hawed, and confessed that he did have a weakness for the phrase, 'the lukewarm Laodiceans', but found the stuff about the Great Beast and Judgement Day all a shade too highly coloured for his taste" (Raban 1996:205-206).

In replication, Bible verses are taken up and re-created as objects inviting reflection on how the verses are supposed to get from God to person as well as person to person. Ideologies of ritual textuality can smooth out gaps in performance as observers construct senses of continuity through comparison—for example, characterizing something as "a faithful rendition" or "a timeless truth," or, conversely, criticizing a lack of perceived flow between past and present. In these broad senses, ritual replication can be sought and enacted in ways that do not depend on linguistic practice (Bielo 2017). In some ways, the discipline of theology can be seen as one 
fundamentally concerned with repetition and replication, with theologians asking how divine words and plans are repeated and hence in some measure recreated in new contexts by new people, churches, and societies.

Indeed, different perspectives on repetition can underlay significant theological controversies. For example, consider early Protestant critiques of the Catholic Mass. To characterize the Eucharist as a sacrifice, Protestant theologians argued, is to violate the understanding of Christ's sacrifice on the cross as an unrepeatable event (Elwood 1999:34-35). Understood as symbols, the elements (bread and wine) become replicable in ways the event itself is not. As Webb Keane observes, Luther, Calvin, and Zwingli stand in increasing distance from Catholic understandings of the nature of Christ's presence in bread and wine: Luther could not fully abandon the idea of transubstantiation, even writing that calling bread a "symbol" of Christ's body was "the greatest idiocy," but Calvin and Zwingli insisted on the symbolic nature of the divine presence (Keane 2007:236-237 n. 13; see also ibid.:60-61). Drawing on the Augustinian distinction between "visible signs and invisible realities," Calvin argued for the indexical force of bread and wine served in Communion: they were connected to God's presence but did not lock God up in material form, or, as Christopher Elwood puts it, “Calvin...emphasizes not only distinction but connection” (1999:62-63). In other words, Christ's sacrifice cannot be repeated, but the symbols of it can be replicated, and this replication always points toward an ultimately "transcendent referent" (ibid.). I will return to the topic of sacrifice and its repetition below in my discussion of Ama'amalele Tofaeono's argument about Christ as the "“perfect pig' of God."

\section{Theology and Anthropology}


I am developing a project based on the work of indigenous Polynesian theologians and the concepts of culture they employ in their theologies. For some of them, replication is a dynamic hinge between ancestral tradition and Christianity, both honoring tradition and configuring Christianity itself as traditional. My interest in theology started before this project began, however. As a graduate student, I began reading Kierkegaard because I had a vague sense that he, as a philosopher of Christianity, might have something to offer an anthropologist studying Christianity. Kierkegaard is best known for his characterization of faith as a leap, a difficult move an individual makes in an attempt to reshape the logically irreconcilable into the passionately true. The core of his philosophy, if one can speak of a core, is his concept of absurdity, or logically irresolvable paradox. For Kierkegaard, Christianity was built on a paradox that could never be puzzled through, only leaped across and into: if one is a believing Christian, one must hold that God is eternal and transcendent, but also came to earth in finite time and immanent form as Jesus.

I found his prose (in English translation) seductive, with its wonderful warp and weft of reason, wordplay, and vivid opinion. And, because I started reading him in the 1990s, his authorial masquerade of multiple voices as well as his insistence on irony and experiential truth sounded current indeed: the 1840s are back! I did not attempt to use him anthropologically, however, until I grappled with repetition, or specifically with Repetition, Kierkegaard's monograph from 1843 (Tomlinson 2014a). In this work, he writes: "[R]epetition is a crucial expression for what 'recollection' was to the Greeks. Just as they taught that all knowing is a recollecting, modern philosophy will teach that all life is a repetition.... Repetition and recollection are the same movement, except in opposite directions, for what is recollected has been, is repeated backward, whereas genuine repetition is recollected forward... If God himself 
had not willed repetition, the world would not have come into existence. Either he would have followed the superficial plans of hope or he would have retracted everything and preserved it in recollection. This he did not do. Therefore, the world continues, and it continues because it is a repetition" (Kierkegaard 1983 [1843]:131, 133). For Kierkegaard, repetition is the temporal mechanism of existence itself, divinely ordained. And it is prospective, looking forward.

Kierkegaard's model of repetition has its limitations. For one thing, it seems to skip over the question of the possibility of newness. For another, in a passage I have not quoted here, he links repetition with happiness and recollection with unhappiness, and this is not a rhetorical flourish but key to the concept even though it ignores contextual nuances in how happiness or unhappiness match up with memory and expectation. In fact, one of Kierkegaard's biographers, Joakim Garff, writes that Kierkegaard's repetition "never takes on its identity as a technical term and has to make do with fervent fantasies of being a weighty philosophical category" (Garff 2005:233). And yet, despite its shortcomings, the Kierkegaardian model of repetition allows scholars think about time and change in ways that depend neither on rupture nor continuity. Repetition is both rupture and continuity, a continuous refashioning that, as another theologian, John Milbank, puts it, requires "positive persistence which both establishes the 'next thing' and secures the reality of the 'initial thing' in the first place" (Milbank 2009:159; see also Coleman 2010; Hovland 2018). It is this understanding, I suggest, that can provide a common meeting point for interdisciplinary dialogue between anthropology and theology.

Many anthropologists would question the wisdom in looking to theology for any kind of theoretical insight, largely because, as Michael Lambek puts it, "whatever the personal profession of individual anthropologists, anthropology has been itself intrinsically a secular discipline... [and] The secular is by definition a perspective that imagines it can look at religion 
from the outside" $(2008: 122,125)$. Nevertheless, Joel Robbins has recently been developing a forceful argument that anthropology can benefit from engaging with theology in order to reignite anthropological imaginations about why otherness matters (Robbins 2006; see also Robbins 2013a, 2013b, collections by Adams and Salamone 2000, Robbins and Engelke 2010, Fountain and Lau 2013, Meneses et al. 2014, Lemons 2018; and Handman 2015, Bialecki 2017, Haynes 2017). Belief in God, for Robbins (at least as I read him), is beside the point for crossdisciplinary engagement: the point is that both theologians and anthropologists believe that otherness fundamentally matters. But anthropology's approach to otherness has changed over the past half-century, and not entirely for the better. Previously, anthropologists held otherness to be a sign of promise, a model for possible transformations in ourselves. The 1980s and 1990s critiques of ethnography and anthropology to some extent recast the "other" as an insult, "othering" an act of neocolonial aggression (Robbins 2013a). Seeking to escape what MichelRolph Trouillot famously called "the savage slot," anthropologists increasingly turned toward what Robbins calls "the suffering slot," seeking in subjects who were displaced, marginal, and oppressed a kind of universal humanity—universal, that is, in the experience of trauma (ibid.). Getting beyond "the suffering slot" is a compelling and valuable anthropological project to the extent that it helps scholars attend in newly sympathetic and critically aware ways to the profundity of human diversity. To recapture the promise of the other, Robbins suggests, means neither denying the reality of trauma nor anthropologists' expertise in analyzing it. Nor does it mean returning to an outdated, essentialist anthropology in which peoples come to represent types, whether carefree Samoans or murderous Yanomamö. Rather, anthropology can transform itself theoretically by recalling its earlier promise while critically and comparatively rethinking it, "imagin[ing] that theologians might either produce theories that get some things right about 
the world [that anthropologists] currently get wrong or model a kind of action in the world that is in some or other way more effective or ethically adequate than their own" (2006:287). This is, in itself, a call for replication of a particular kind: a call to return to, and recreate, anthropology's original impulse of locating inherent value in otherness in order to develop what Robbins calls an "anthropology of the good."3

\section{Repetition in Creation: The Gospel According to Tagaloa}

The story of the world's creation in the first chapter of Genesis is inherently repetitive. God works day by day. The universe comes into existence with God speaking and evaluating: "And God said" appears ten times; "And God saw," seven. Six verses close with "and it was so"; "and God saw that it was good" finishes the following verse three times. The story's rhythmic sequence is well known, and I do not want to belabor the point that this is a repetitive text, with the repetition signifying not mimicry but the building of form and energy. The model of creation in the first chapter of Genesis is invoked at other points in the Bible, such as in Psalm 8 and Jeremiah 4 (Alter 1985:117, 154). ${ }^{4}$

Thus, I suggest, Kierkegaard was not just being idiosyncratic when he looked for repetition in creation. It was poetically present in the foundational text. But investigations of repetition and creation can follow paths other than Kierkegaard's, as seen in the work of the Samoan theologian Ama'amalele Tofaeono, on which I focus in the rest of this article. Tofaeono is an ordained minister in the Congregational Christian Church of American Samoa and, during the period of my fieldwork in American Samoa, served as the vice president of the Kanana Fou Theological Seminary in Tafuna. ${ }^{5}$ [Insert figures 2 and 3 here] 
Tofaeono is a "contextual theologian," meaning he situates culture as foundational to human experience of divinity. From a strong contextual-theological viewpoint, all theology should be contextual, and classical theology (Systematic Theology) simply ignores its own cultural situation to its detriment (Bevans 1992). In Tofaeono's view, ancient Samoans knew the "spirit of Christ" in their own terms through the Samoan deity Tagaloa before European missionaries showed up in the islands. This means that understanding the "Gospel," for Tofaeono, means to some extent rejecting the deformations of traditional knowledge and practice caused by missionaries. In short, the Gospel and Christianity need to be distinguished from each other, for the latter does not necessarily bear the former in a culturally relevant way. Ancient Samoans knew the Gospel: the Gospel according to Tagaloa. Christian missionaries introduced new understandings of the Spirit of Christ which relied on a culturally inappropriate, and socially destructive, model of God as a male father figure and God's Spirit as locked up in a human man, Jesus of Nazareth, rather than present in the whole of creation.

Tofaeono is also an "eco-theologian," meaning he brings a holistic environmental focus to his theological scholarship. In his Bachelor of Divinity thesis, written at the ecumenical Pacific Theological College in Suva (Tofaeono Siolo II 1993), ${ }^{6}$ he offers a moving personal account of his developing interest in uniting ecological awareness and theological inquiry, which I will quote at length:

The land and sea hold a very special place in my heart, not merely because they are the home of my ancestors, but because the fanua (land and sea) is the source of life and the passport and hope for a brighter future to many of us who grew up in the rural villages in Samoa. Unlike many people whose advancement was supported through the incomes of 
their parents and relatives working in the government, business, and the church, my educational journey and survival was enabled by the fruits of hard labour on the land and in the sea.

The visual image of my sweating parents gardening, raising chickens, pigs, and fishing are treasured memories. In their toils and struggles, they cultivated the land and fished the sea, not only to support the large aiga (family), but to earn money for our education....

Upon completing school, I worked for the National Parks and Reserve Areas in the Department of Agriculture and Forestry Division in Western Samoa. Although I was employed as a caretaker, working to conserve nature, the land and marine wildlife, I did not fully appreciate the nature of such a job, nor understand its significance in human lives. I was constantly influenced by my associations of 'the good life' with office employment. I often asked myself why I was serving trees, birds, fish, and the natural environment and not people. Most of all, I struggled with the question of whether the outcome of my parents' toils was that I should return and care for what has been the only means of survival for us.

Reflecting back on these memories has created an interest in me to confront the reality of my bond and connectedness to the fanua, especially now, when I have left my father, the grave of my mother, and my aiga to pursue whatever the Lord has called me to do...

This 'Quest for a Samoan Theology of Creation' [the title of his thesis] is not only a desire for reconciliation with the womb of my experience (land, sea and sky), which at times has been taken for granted, but it is also an attempt to answer two main questions: 
Why am I alienated from, and thus an abuser of God's creation? What are ways to respond, through using God-given knowledge, to the crisis that makes my fanua (land and sea) suffer? (Tofaeono Siolo II 1993:xi-xiii)

In coming to think about land and sea as sacred, it must be noted, Tofaeono's personal experience is enmeshed with broad social and intellectual movements. Influences on ecotheology can be traced along various paths, but the immediate stimulus for modern eco-theology is the environmental movement which began in the USA and western Europe in the midtwentieth century (Kearns 2004). In Oceania, specific environmental concerns which have motivated theological scholarship include nuclear testing in French Polynesia, deforestation, and the effects of climate change. Another influence on Tofaeono's eco-theology is the indigenous renaissance in Oceania which gained force in the 1970s, flowered in the 1980s, and found its most eloquent expression in the writings of the Tongan anthropologist, novelist, and poet Epeli Hau'ofa in the 1990s—-whose work, it must be observed, is cited often by anthropologists and theologians alike (see especially Hau'ofa 1994).

Tofaeono's doctoral dissertation, published as a book in the same year, begins by referring to Lynn White Jr.'s influential argument from 1967 that (as Tofaeono summarizes it) "the glorious success of Christianity over so-called paganism/heathenism, as well as the monotheistic faith orientation of the Judeo-Christian tradition, are at the root of ecological disasters" (Tofaeono 2000:13; in this article, I cite Tofaeono's published version). For Tofaeono, pre-Christian Samoa was literally Edenic: he writes of "the centrality of a reverence for and sustainability of nature," and states explicitly that "The way in which Samoans viewed, experienced and related to the world could be seen as an equivalent of Eden before the Fall of 
humankind, and the lifestyle can be described as a self-sufficient and reciprocal kind of communal living," one dedicated to "the balance of life-supporting systems" (Tofaeono 2000:90). This might sound romantic, but Tofaeono acknowledges that "unfavourable conditions, negative customs and behaviours of Samoans naturally existed" (ibid.; and crucially, he goes on to say that Eden can be anywhere, "the place where we find life in and with God in its fullness,”2000:293). The key point is that ancient Samoa, according to Tofaeono, was relationally integrated in the most holistic sense possible: people, nature, and the old gods were existentially joined in a way that would be disrupted and then forgotten with the arrival of Christian missionaries.

Looking to Samoan myth as the foundation of this holistic ecological order, Tofaeono notes regional differences. In Manu'a, eastern Samoa (now American Samoa), the world was created from above, whereas in Upolu and Savai'i in Samoa's west, it was created from below (Tofaeono 2000:176-179). In the book of Genesis, he writes, God creates by separating and then ordering, whereas in Samoan myth, the deity Tagaloa does not speak the world into being but rather, "natural laws...brought forth the order of everything"; in Genesis, chaos is overcome by a preexisting God, whereas in Samoa, Tagaloa did not preexist the world, and "chaos itself worked out/arranged order from within itself" (2000:231, emphasis deleted; see also Sahlins 1985 and Gell 1995 on Eastern Polynesian understandings of creation).

The arrival of missionaries, in Tofaeono's argument, severed the links Samoans had recognized and cultivated between humanity and all of the natural and spiritual world, replacing an appreciation of holistic creation with a focus on individual salvation for humans who stand apart from the natural order. Moreover, it introduced the unfortunate concept of humans having "dominion" (per Genesis 1:26, 28) over all of God's creation, a notion that has led to worldwide 
ecological disaster. If Tofaeono's complex and elegant argument can be summed up in a few words, it would be his statement near the end of his book: "there is no salvation outside creation" (2000:285). Both creation and salvation are "inseparable poles of the reality of life" (ibid.). What is needed now, he argues, is a return to Samoan first principles.

To get to these principles, he analyzes several Samoan language terms including 'aiga (often translated as "family") and mana (the classic Oceanic term and concept, often associated with spiritual efficacy, which has proven remarkably durable and adaptive in the twentieth and twenty-first centuries; Tomlinson and Tengan 2016). In Tofaeono's expansive theology, 'aiga is family in the widest possible sense: it stands for "the wholeness of Samoan life," joining divinity, nature, and humanity (Tofaeono 2000:30). Mana, for Tofaeono, "belongs to those terms that cannot be clearly explained in words, but must be experienced"; Christ is "the mana of God," and the deity Tagaloa was "the possessor of all mana" in pre-Christian Samoa (2000:169, $253,170)$.

In arguing for the replication of Samoan wisdom, Tofaeono draws on both Samoan and non-Samoan sources. A key interlocutor is the German theologian Jürgen Moltmann, the source of a distinction Tofaeono uses between "creatio originalis," "creatio continua," and "creatio nova" (Tofaeono 2000:238-239). As Moltmann writes (in a source which Tofaeono cites), "we shall interpret Christ's mediation in creation in three separate strands or movements: 1 . Christ as the ground of the creation of all things (creatio originalis); 2 . Christ as the moving power in the evolution of creation (creatio continua); and 3. Christ as the redeemer of the whole creation process (creatio nova)" (Moltmann 1990:286; see also Moltmann 1985:55 and Moltmann 1993, also cited by Tofaeono). In light of the anthropological models of replication discussed earlier, the key point is that creation is portrayed as repetitive in a sustained, interactive way. Creation is 
still taking place. It did not end with Genesis. For Tofaeono and Moltmann — and Kierkegaard, in his idiosyncratic way - creation is continuous. Humans participate in it by replicating a constellation of relationships: social relationships, natural relationships, devotional relationships, ecclesiastical and ecumenical relationships. Creation is recreated, in Samoa and everywhere else. As I read Tofaeono's theology, replication operates at two distinct levels. First, the original Samoan understandings of and engagements with creation through concepts like 'aiga, mana, and fanua must be relearned so they can be reexpressed. Second, their reexpression can itself be an act of participating anew in creation.

I asked Tofaeono to elaborate his ideas and their implications during an interview with him at the Kanana Fou Theological Seminary on May 2nd, 2016:

Tomlinson: ...[Y] ou use Jürgen Moltmann and this division between creatio originalis, creatio continua, creatio nova. And I found that interesting, especially creatio continua, this idea of continuous creation.... My question is: How do we participate in creation? How do humans - what are the actual acts we do that enable us to be continually creating in this sense?

Tofaeono: I think the key role of us human beings is to be co-creators with God, and as stewards of God's creation. Because we are latecomers in accordance with the myth of creation in Genesis. We were the ones who were lastly formed or made by God, so we are latecomers. We have to appreciate our status in creation [he laughs] as caregivers or caretakers. And we have to recognize the fact that we are here only for that period of time, but the land, the ocean, and the skies will be there forever. So after seventy or 
ninety years we just go down, go back to the ocean or to the land. And then our role nowadays is to be co-creators with God. And that's where continuity of creation-we are participating in that continuation of God's creation.

Tomlinson: Does this have a political implication? Does this mean we should be active in raising ecological awareness, or just does it mean we should live our lives a certain way?

Tofaeono: That's part of our commitment, not only to live our lives in accordance to the happenings of the world nowadays, when we think of the issues globally. And also we have to be proactive locally, because sometimes we have to...think globally and act locally, I think that's the key. So when we are very much concerned with global warming, for example, and changing climate, we have to do something locally. We also have to sacrifice ourselves a little bit in terms of the [consumption] of oil, gas for our vehicles, and that's where I think we can participate in the mending of these broken environmental issues.

The environmentalist adage to think globally and act locally, repeated here by Tofaeono and illustrated by the example of rethinking our use of fossil fuels, might be seen as an act of recuperation rather than repetition as such. The larger point, however, is that for Tofaeono, acting with responsible ecological ethics means providing ongoing service as "caretakers" in which we are ultimately "co-creators with God." 


\section{Repetition in Salvation: Behold, the Pig of God}

Figures in the Bible, according to St. Augustine, are both literally what they seem to be but also tokens that "prefigure" later ones. Jerusalem is both an earthly city and a heavenly place. Adam, the first human, and the "suffering servant" of the Book of Isaiah are both themselves and also stand for Christ (Markus 1996:6-7). Modern American fundamentalists take this logic a step further and frequently interpret unfolding events in biblically typological terms. The politically active church leader Jerry Falwell was especially energetic in this regard, suggesting at times that his own character and experiences should be understood in terms of the character and experiences of Jesus, Joshua, Jacob, David, and Paul (Harding 2000). Elsewhere, I have noted how Fiji's various coup leaders have been linked typologically by themselves and others to Jeremiah, Moses, Judas, Joshua, and the martyr Stephen (Tomlinson 2010, 2011).

Taking this kind of repetition seriously in a literal and embodied sense, millennialist Christians expect Jesus to return to earth soon in his Second Coming. Salvation requires this moment of repetition. Followers of the Paliau Movement - a social reform movement based in Manus, Papua New Guinea, which evolved into a messianic one — believe that the life of Paliau Maloat ( 1911-1991) was the Second Coming of Jesus. A story of the Movement's beginnings, which portrayed Paliau's actions as divinely inspired, originally made it clear that Jesus and Paliau were separate characters (see e.g. Schwartz 1957:149), and even near the end of his life he was still being called "the last prophet" rather than identified as Jesus himself (Otto 1998:72). However, as the anthropologist Ton Otto has written, "public references to his religious status became more frequent and explicit during his last years, culminating in his declaration as the Melanesian Jesus in 1990. When I was in Manus in 1988, there was a discussion about Paliau's nearing departure from this world, and Paliau had to state explicitly that, if he chose to leave, he 
would not return after three days!" (Otto 1998:86). When I visited Manus for five weeks in 2000, I found his followers expecting Paliau/Jesus to return again in a Third Coming — repetition's repetition, as it were. [Insert figure 4 here]

If Paliau returns to Manus as the third coming of Christ, this will be an act of "spirit writing," in Webb Keane's (2013) sense of the term. Keane uses the term to identify the ways in which writing's materiality mediates the "power-laden relationship across ontological difference - for instance, between living humans and a world of gods or spirits" (2013:2; see also Keane 1997a, 1997b, 2003, 2007). He draws on Michael Silverstein's (2003) use of the term transduction to describe how material transformations signify the possibility of crossing an ontological gap:

semiotic transduction aims to tap into the power that can be obtained by the very act of transforming something from one semiotic modality to another. Although it is probably true that in most cases the divine source of the words is considered by practitioners to be the ultimate source of power, this alone does not explain the practice. Rather, the ability of humans to gain access to that divine power depends on the act of transformation. It seems these practices develop a notion that the very capacity to alter or move among semiotic modalities is itself a source of efficacy. (Keane 2013:2, emphasis in original; see also Handman 2013)

The key point, then, is that figures like Paliau are —in both anthropological and theological terms - not only made real in words, and not only in flesh, but also in the transformations between them. I will return to this point below. 


\section{The Perfect Pig of God}

Repetition is both a literary feature of texts like the Bible and, in replication, a way of acting in the world - a way that draws on past models but has a prospective orientation. Recall Urban's initial distinction between internal repetition and external replication and his emphasis on the link between them. For religious believers like Falwell's Baptists or adherents of Paliau's Movement, text and action resonate strongly in building up and drawing out the possibilities, senses, and consequences of replication. For Christians, Jesus was both historical and eternal. This paradox gave Kierkegaard's notion of “absurdity” its gravity, and is echoed in Tofaeono's own quasi-Kierkegaardian statement that "the communion of the divine is both eternal and ordinary" (2000:242). A new incarnation can be seen as an act of replication: God's Spirit is expressed anew in the world, the same "thing" is refigured in a new context. As liberationist and contextual theologians have insisted, the replication of Jesus as character, narrative, and mission needs to take shape in ways that make local sense. ${ }^{7}$

This does not only mean producing images of Christ as a local character - as an Asian or African man, for example, although those modes of representation are popular. It also means framing the whole character, narrative, and mission of Christ in a way that addresses a society's dominant concerns at a particular historical moment (Pelikan 1985). Tofaeono's work, itself a late-twentieth and early twenty-first century marriage of contextual and ecological theology, is anchored in a society (Samoa, along with American Samoa) undergoing significant transformations in social organization, mobility patterns, economy, land use, and the cultivation of traditional knowledge. In this context, Tofaeono articulates an understanding of the "cosmic Christ," or Christ as "the foundation for the very structure of the universe and the belief that "the 
Logos of God is in the whole universe'.... The Creator could be described as 'the one who is...,' while creatures had their being by derivation from the Creator and participation in the Creator and they could not 'be of themselves"' (Pelikan 1985:66). Understanding Christ as "cosmic," for Tofaeono and like-minded theologians, does not mean dismissing his incarnation as an Israeli carpenter two millennia ago, but it does mean expanding the understanding of Christ as spiritually active in the world's creation and therefore not limited to the biblical narrative or anthropocentric categories.

In 2005, Tofaeono developed a paper he had delivered at Union Theological Seminary as an article for the Pacific Journal of Theology. In it, he turns to Melanesia (rather than Samoa or Polynesia more broadly) and observes Melanesians' well-known affection for pigs. The key point for Tofaeono is not only that Melanesians cherish their pigs, but also that they sacrifice them to restore community harmony (among other purposes). In this way, pigs are eminently Christlike, and Christian sacrifice is necessarily enmeshed in a dynamic of repetition: Christ's death on the cross occurs again with the sacrifice of a pig in Melanesia. Merging his ecotheological focus on creation with his appreciation of the need to understand salvation in culturally appropriate terms, Tofaeono writes: "[A]11 of life is interdependent. If the sacrifice of Jesus is restricted to a one-time act on behalf of humans, it does not reach far enough to the whole of the cosmos" (Tofaeono 2005:96).

Tofaeono acknowledges that pigs are not honored in the Bible ("There is no such thing as 'pig-love' in the Bible"; Tofaeono 2005:84), and he refers to the verses Proverbs 11:22, Isaiah 65:4 and 66:3. ${ }^{8}$ Moreover, when Jesus cleanses a man of the demons possessing him, he sends them into a herd of two thousand pigs who promptly drown themselves in the ocean. For Melanesian cultural contexts, however, Tofaeono argues that "the power of pig symbolism 
and...sacrifice is still an inspiring force.... It has the power to renew and mend relationships. It is a channel for a 'Christic-spark' or a 'Christ-emanating light' that moves the hearts and persons of communities to mend relationships and to embrace and appreciate the gifts of others" (Tofaeono 2005:94). He mentions a ceremony with Melanesian participants held at All Saints Anglican Church in East St. Kilda, Melbourne, in which a sacrificed pig's head was set on the church's high altar (see also Byrne 2002). Tofaeono concludes his article with the observation, "If John the Baptist had lived in one of the islands in Oceania 2000 years ago, and had encountered the Christ walking by, he would surely have exclaimed, 'Behold, the Pig of God that takes away the sins of the world"' (2005:98; the biblical parallel is John 1:29, "The next day John seeth Jesus coming unto him, and saith, Behold the Lamb of God, which taketh away the sin of the world"). In short, the answer to Tofaeono's guiding question- "Can Jesus symbolically and/or metaphorically be portrayed as a Pig—a 'Perfect Pig' of God?' (2005:83)— is a resounding yes.

Tofaeono is not the first or only Oceanic author to identify pigs with Christ. Wesis Toap developed a Master of Theology thesis to craft what he called "A Melanesian Pig Theology," arguing, as Tofaeono would also do for pre-Christian Samoa and the deity Tagaloa, that Christ was present in the pre-Christian Papua New Guinea highlands: "Christ was in Woala, in Yeki, even before he became incarnate in Jesus... Since incarnation and salvation is a process, Christ used and uses nature and human culture or activities that are potential sources or links to save humanity. In the Woala context, the pig culture can be interpreted as that potential source or link, as playing the salvific, incarnation role of Christ" (Toap 1998:82; see also Callick 1977:260, Solomone 2000:98-99). The connection is not only made by theologians, either: Guhu-Samane of Papua New Guinea, recalling a precolonial practice of presenting a roast pig (hoo dzoba) as "a 
sacrificial lamb of sorts" to a group that had had a member killed, now sometimes call Jesus “"the [sacrifical] Roast Pig' of God" (Handman 2015:168, 282n3; brackets in original). But it must also be acknowledged that not all Oceanic theologians appreciate the comparison. A Tongan Methodist theologian, Ma'afu 'o Tu'itonga Palu, published a string of articles in which he dismissed contextual theology's emphasis on culture and held up the model of the "perfect pig" for criticism as un-biblical (Palu 2002, 2003, 2005).

Keane's discussion of "spirit writing" suggests that replication's perceived efficacy or value can lie in its shift across semiotic modes. Forms change, although they are held to represent the "same" thing (Jesus is Christ; Paliau is Christ; so is a pig), and indexical links are retained. As Tofaeono put it during my interview with him at Kanana Fou on May 2nd, 2016:

...[W]e bring the sacrifice of Jesus Christ in personal terms. But the sacrifice itself, when we try not to limit it within the sacrifice of Christ, there are lots of other sacrifices. Even other parts of the creation are sacrificed so that we can live. Like, we just cut the cabbages or the tomatoes for our food. So they are killed, they are sacrificed for my benefit, so to say, so that I can live. But the problem with the Christian understanding of the sacrifice of Christ, it's only for the benefit of the human beings, not for other parts of nature, the environment. So it's very exclusive in that sense. But to be inclusive, to count on other sacrifices [of?] nature, I think that's where I come in with this, this period of the cosmic Christ, and the sacrifices of all other elements or other components of nature.

As this excerpt makes clear, Tofaeono sees salvation depending in part on recognition of repetition. Paliau and pigs, and even cabbages and tomatoes, can manifest divine spirit. This is 
spirit writing in words and flesh, blood and soil. The key is to see how sacrifice and salvation are intertwined, the latter depending in part on an appreciation of how the former works in a universal cosmic scheme. A Christian, Samoan or otherwise, should in Tofaeono's view be able to recognize the spirit of Christ in whatever form it is remade and reexpressed.

\section{Conclusion}

There is an obvious limit to the contexts in which arguments such as Tofaeono's can be replicated. Samoan Congregationalists tend to be quite conservative, and although they express a robust and thoroughgoing appreciation for the importance of the metacultural category of the "Samoan way" (fa'asāmoa), declaring in a sermon that Tagaloa is Christ might earn the preacher a rebuke from elders.

A key point to bear in mind when reading theology through an anthropological lens, then, is that theological arguments have their own social lives - an obvious point, perhaps, but a crucial one to recall (and repeat when necessary). For the approach I have taken here, it is critical to keep two things in mind. First is the fact that Tofaeono has succeeded within the academic settings of theology schools and the institutional settings of church leadership. Second is the fact that Samoa and American Samoa are intensely Christian societies. As Manfred Ernst (1994:167) puts it, writing of independent Samoa (although I believe his words apply with equal force to American Samoa), "there is no other Pacific Island group, known to me, where the society and the mainline churches are so closely knit together, and where the church has had and still has such an impact on nearly every aspect of life" (see also Ernst 2006). Simply put, Christian theology matters more in Samoa and American Samoa than it does in most other places. Someone like Tofaeono is well positioned to make an intellectual difference in Samoan society, 
so his theological approach to repetition in creation and salvation should be of interest to anthropologists who want to know how people in Samoa think about divinity, humanity, society, and transformation.

If anthropologists and theologians are justified in seeking enhanced and expanded interdisciplinary dialogues, then focusing on processes of repetition offers the possibility of gaining sharper insights than does simply focusing on content. Repetition does not determine anything, and as Johnstone pointed out, can signify almost anything; but it often serves to emphasize that a particular sign deserves special attention and represents something meant to endure. Repetition is itself a sign, and both anthropologists and theologians potentially have much to gain by considering its creative aspects. Linguistic attention to replication as a form of repetition gives us ethnographic purchase on the ways in which repetition can be both imitative and creative, an index of a value like fidelity to the past and also an icon of that value's new generation in the world.

\section{Acknowledgments}

Funding for field research came from the Australian Research Council (Future Fellowship FT110100524). Early versions of this paper were presented as a Herbst Seminar at the Australian National University and a paper at the 2014 American Anthropological Association conference panel organized by Andreas Bandak and Simon Coleman. For comments, I am grateful to Andreas and Simon as well as James S. Bielo, Ghassan Hage, and the reviewers for this journal. For library assistance in Fiji and Samoa, I thank Nalini Premadish and Uesile Tupu. Finally, this article, and the larger project of which it is part, could not have come to fruition without the patient and productive support of Ama'amalele Tofaeono, to whom I am indebted. 


\section{Sources}

Adams, Walter Randolph, and Frank A. Salamone, eds. 2000. Anthropology and Theology: Gods, Icons, and God-Talk. Lanham, MD: University Press of America.

Alter, Robert. 1985. The Art of Biblical Poetry. New York: Basic Books.

Bandak, Andreas, and Lars Højer, eds. 2015. The Power of Example: Anthropological Explorations in Persuasion, Evocation, and Imitation. Journal of the Royal Anthropological Institute 21(S1).

Banner, Michael. 2014. The Ethics of Everyday Life: Moral Theology, Social Anthropology, and the Imagination of the Human. Oxford: Oxford University Press.

Bauman, Richard, and Charles Briggs. 1990. Poetics and Performance as Critical Perspectives on Language and Social Life. Annual Review of Anthropology 19: 59-88.

Bevans, Steven B. 1992. Models of Contextual Theology. Maryknoll, NY: Orbis Books.

Bialecki, Jon. 2017. A Diagram for Fire: Miracles and Variation in an American Charismatic Movement. Berkeley: University of California Press.

Bielo, James S., ed. 2009. The Social Life of Scriptures: Cross-Cultural Perspectives on Biblicism. New Brunswick, NJ: Rutgers University Press.

- 2017. Replication as Religious Practice, Temporality as Religious Problem. History and Anthropology 28(2): 131-148.

Briggs, Charles L., and Richard Bauman. 1992. Genre, Intertextuality, and Social Power. Journal of Linguistic Anthropology 2: 131-172.

Byrne, Louise. 2002. Sanap Wantaim: Melanesia West Papua. Arena Magazine 62: 13-14.

Callick, Rowan. 1977. Appendix: An Account of a Theologians Workshop. In Christ in Melanesia: Exploring Theological Issues (biannual issue of Point), pp. 256-261. Goroka: Melanesian Institute for Pastoral and Socio-Economic Service.

Coleman, Simon. 2010. An Anthropological Apologetics. South Atlantic Quarterly 109(4): 791-810.

Duranti, Alessandro, and Charles Goodwin, eds. 1992. Rethinking Context: Language as an Interactive Phenomenon. Cambridge: Cambridge University Press.

Ehrman, Bart D. 2005. Misquoting Jesus: The Story Behind Who Changed the Bible and Why. New York: HarperSanFrancisco.

Eisenlohr, Patrick. 2010. Materialities of Entextualization: The Domestication of Sound Reproduction in Mauritian Muslim Devotional Practices. Journal of Linguistic Anthropology 20(2): 314-333.

Ellwood, Christopher. 1999. The Body Broken: The Calvinist Doctrine of the Eucharist and the Symbolization of Power in Sixteenth-Century France. New York: Oxford University Press. 
Engelke, Matthew, and Joel Robbins, eds. 2010. Global Christianity, Global Critique. South Atlantic Quarterly 109(4).

Ernst, Manfred. 1994. Winds of Change: Rapidly Growing Religious Groups in the Pacific Islands. Suva: Pacific Conference of Churches.

- 2006. Globalization and the Re-Shaping of Christianity in the Pacific Islands. Suva: Pacific Theological College.

Fountain, Philip, and Sin Wen Lau, eds. 2013. Anthropological Theologies: Engagements and Encounters. The Australian Journal of Anthropology 24(3).

Gell, Alfred. 1995. Closure and Multiplication: An Essay on Polynesian Cosmology and Ritual. In Cosmos and Society in Oceania, eds. Daniel de Coppet and André Iteanu, pp. 21-56. Oxford: Berg.

Goodman, Jane E., Matt Tomlinson, and Justin B. Richland. 2014. Citational Practices: Knowledge, Personhood, and Subjectivity. Annual Review of Anthropology 43: 449-463.

Haeri, Niloofar. 2013. The Private Performance of Salat Prayers: Repetition, Time, and Meaning. Anthropological Quarterly 86(1): 5-34.

Handman, Courtney. 2013. Mediating Denominational Disputes: Land Claims and the Sound of Christian Critique in the Waria Valley, Papua New Guinea. In Christian Politics in Oceania, eds. M. Tomlinson and D. McDougall, pp. 22-48. New York: Berghahn.

—. 2015. Critical Christianity: Translation and Denominational Conflict in Papua New Guinea. Berkeley: University of California Press.

Harding, Susan Friend. 2000. The Book of Jerry Falwell: Fundamentalist Language and Politics. Princeton: Princeton University Press.

Hau'ofa, Epeli. 1994. Our Sea of Islands. The Contemporary Pacific 6(1): 148-161.

Haynes, Naomi. 2017. Moving by the Spirit: Pentecostal Social Life on the Zambian Copperbelt. Berkeley: University of California Press.

Hovland, Ingie. 2018. Beyond Mediation: An Anthropological Understanding of the Relationship Between Humans, Materiality, and Transcendence in Protestant Christianity. Journal of the American Academy of Religion 86(2): 425-453.

Johnstone, Barbara, et al. (42 coauthors). 1994. Repetition in Discourse: A Dialogue. In Repetition in Discourse: Interdisciplinary Perspectives, vol. 1, ed. B. Johnstone, 1-20. Norwood, NJ: Ablex.

Keane, Webb. 1997a. Religious Language. Annual Review of Anthropology 26: 47-71.

- 1997b. Signs of Recognition: Powers and Hazards of Representation in an Indonesian Society. Berkeley: University of California Press. 
- 2003. Semiotics and the Social Analysis of Material Things. Language and Communication 23(34): 409-425.

- 2007. Christian Moderns: Freedom and Fetish in the Mission Encounter. Berkeley: University of California Press.

- 2013. On Spirit Writing: Materialities of Language and the Religious Work of Transduction. Journal of the Royal Anthropological Institute 19(1): 1-17.

Kearns, Laurel. 2004. The Context of Eco-Theology. In The Blackwell Companion to Modern Theology, ed. G. Jones, 466-484. Malden, MA: Blackwell.

Kierkegaard, Søren. 1983 [1843]. Repetition: A Venture in Experimenting Psychology. In Fear and Trembling/Repetition, eds. and trans. H.V. Hong and E.H. Hong. Princeton: Princeton University Press.

Lambek, Michael. 2008. Provincializing God?: Provocations from an Anthropology of Religion. In Religion: Beyond a Concept, ed. H. de Vries, 120-138. New York: Fordham University Press.

Lemons, J. Derrick, ed. 2018. Theologically Engaged Anthropology. Oxford: Oxford University Press.

Lütgert, Wilhelm. 1934. Schöpfung und Offenbarung: Eine Theologie des ersten Artikels. Gütersloh: C. Bertelsmann.

Markus, R.A. 1996. Signs and Meanings: World and Text in Ancient Christianity. Liverpool: Liverpool University Press.

Meneses, Eloise, Lindy Backues, David Bronkema, Eric Flett, and Benjamin L. Hartley. 2014. Engaging the Religiously Committed Other: Anthropologists and Theologians in Dialogue. Current Anthropology 55(1): 82-104.

Moltmann, Jürgen. 1985. God in Creation: A New Theology of Creation and the Spirit of God. San Francisco: Harper \& Row.

—. 1990. The Way of Jesus Christ: Christology in Messianic Dimensions. London: SCM Press.

- 1993. Christ in Cosmic Context. In Christ and Context: The Confrontation between Gospel and Culture, eds. H. Regan and A.J. Torrance, pp. 180-191. Edinburgh: T\&T Clark.

Otto, Ton. 1998. Paliau's Stories: Autobiography and Automythography of a Melanesian Prophet. Focaal 32: 71-87.

Palu, Ma'afu 'o Tu'itonga. 2002. Pacific Theology. Pacific Journal of Theology, series II, 28: 21-53.

- 2003. Pacific Theology: A Reconsideration of Its Methodology. Pacific Journal of Theology, series II, 29: 30-58.

- 2005. Contextualisation as Bridging the Hermeneutical Gap: Some Biblical Paradigms. Pacific Journal of Theology, series II, 34: 22-43. 
Pelikan, Jaroslav. 1985. Jesus through the Centuries: His Place in the History of Culture. New Haven: Yale University Press.

Raban, Jonathan. 1996. Bad Land: An American Romance. London: Picador.

Robbins, Joel. 2006. Anthropology and Theology: An Awkward Relationship? Anthropological Quarterly 79: 285-294.

- 2013a. Beyond the Suffering Subject: Toward an Anthropology of the Good. Journal of the Royal Anthropological Institute 19(3): 447-462.

—. 2013b. Let's Keep It Awkward: Anthropology, Theology, and Otherness. The Australian Journal of Anthropology 24(3): 329-337.

Sahlins, Marshall. 1985. Islands of History. Chicago: University of Chicago Press.

Schwartz, Theodore. 1957. The Paliau Movement in the Admiralty Islands, 1946 to 1954. Ph.D. dissertation, University of Pennsylvania.

Shoaps, Robin. 1999. The Many Voices of Rush Limbaugh: The Use of Transposition in Constructing a Rhetoric of Common Sense. Text 19(3): 399-437.

—. 2002. "Pray Earnestly": The Textual Construction of Personal Involvement in Pentecostal Prayer and Song. Journal of Linguistic Anthropology 12(1): 34-71.

Silverstein, Michael. 2003. Translation, Transduction, Transformation: Skating "Glossando" on Thin Semiotic Ice. In Translating Cultures: Perspectives on Translation and Anthropology, eds. P.G. Rubel and A. Rosman, pp. 75-105. Oxford: Berg.

Silverstein, Michael, and Greg Urban, eds. 1996. Natural Histories of Discourse. Chicago: University of Chicago Press.

Solomone, Kafoa. 2000. Ecumenism in Oceania. Pacific Journal of Theology, series II, 24: 88-106.

Toap, Wesis Porop. 1998. A Melanesian Pig Theology: An Anthropological/Theological Interpretation of a Pig Culture amongst the Woala Highlanders of Papua New Guinea. Master of Theology thesis, Pacific Theological College, Suva.

Tofaeono Siolo II, Ama'amalele. 1993. A Quest for a Samoan Theology of Creation. Bachelor of Divinity thesis, Pacific Theological College, Suva, Fiji.

Tofaeono, Ama'amalele. 2000. Eco-Theology: Aiga-The Household of Life, A Perspective from Living Myths and Traditions of Samoa. Erlangen: Erlanger Verlag für Mission und Ökumene.

- 2005. Behold the Pig of God: Mystery of Christ's Sacrifice in the Context of Melanesia-Oceania. Pacific Journal of Theology, series II, 33: 82-102.

Tomlinson, Matt. 2010. Compelling Replication: Genesis 1:26, John 3:16, and Biblical Politics in Fiji. Journal of the Royal Anthropological Institute 16(4): 743-760. 
—. 2011. The True Me: Individualism and Biblical Types in Fijian Methodism. In Managing Modernity in the Western Pacific, eds. Martha Macintyre and Mary Patterson, pp. 147-171. St. Lucia: University of Queensland Press.

- 2014a. Bringing Kierkegaard into Anthropology: Repetition, Absurdity, and Curses in Fiji. American Ethnologist 41(1): 163-175.

—. 2014b. Ritual Textuality: Pattern and Motion in Performance. New York: Oxford University Press.

Tomlinson, Matt, and Ty P. Kāwika Tengan. 2016. Introduction: Mana Anew. In New Mana:

Transformations of a Classic Concept in Pacific Languages and Cultures, eds. M. Tomlinson and T.P.K. Tengan, pp. 1-36. Canberra: ANU Press.

Urban, Greg. 1986. Ceremonial Dialogues in South America. American Anthropologist 88(2): 371-386.

—. 1991. A Discourse-Centered Approach to Culture: Native South American Myths and Rituals. Austin: University of Texas Press.

- 1994. Repetition and Cultural Replication: Three Examples from Shokleng. In Repetition in Discourse: Interdisciplinary Perspectives, vol. 2, ed. B. Johnstone, 145-161. Norwood, NJ: Ablex.

- 1996a. Entextualization, Replication, and Power. In Natural Histories of Discourse, eds. M. Silverstein and G. Urban, pp. 21-44. Chicago: University of Chicago Press.

- 1996b. Metaphysical Community: The Interplay of the Senses and the Intellect. Austin: University of Texas Press.

—. 2001. Metaculture: How Culture Moves through the World. Minneapolis: University of Minnesota Press.

Valeri, Valerio. 1989. Death in Heaven: Myths and Rites of Kinship in Tongan Kingship. History and Anthropology 4: 209-247.

White, Jr., Lynn. 1967. The Historical Roots of Our Ecologic Crisis. Science 155 (3767): 1203-1207.

\section{Notes}

${ }^{1}$ Scholars of Peircean semiotics have emphasized that indexicality and iconicity are never exclusive: "Unless materially embodied and teamed with indexicality...iconicity remains as unstable as the shapes of clouds as they morph and file across the sky" (Lempert 2014:386-387).

${ }^{2}$ Eisenlohr investigates Mauritian Muslims' use of cassettes and compact discs to play recorded praise poetry, arguing that they embrace these media because playing these recordings accords with their ideas about the perfect transmission of holy discourse. In developing his argument, Eisenlohr identifies three "strategies of entextualization," ways in which people turn "performed discourse" into "a relatively bounded, recognizable, and replicable chunk of discourse we call text, which can be detached from one 
discursive context and fit and grafted into others" (Eisenlohr 2010:320; on entextualization see also Bauman and Briggs 1990; Briggs and Bauman 1992; Duranti and Goodwin 1992; Goodman, Tomlinson, and Richland 2014; Silverstein and Urban 1996; Tomlinson 2014b).

${ }^{3}$ Some theologians have drawn on anthropology in turn as a way of pushing their discipline into new kinds of commitment and inquiry. A notable example is Michael Banner, who in The Ethics of Everyday Life (2014) uses anthropology in order to challenge and rethink moral theology. With reference to the Apostles' and Nicene Creeds' compact summaries of Christ's life (he was "conceived, born, suffered, died, and buried," in Banner's even shorter summary), Banner argues that moral theology and bioethics botch the job of apprehending the meaning of these events and their ethical weight in people's daily lives. Moral theology, he writes, focuses on "hard cases" rather than routine ones, and comes to conclusions which can seem, to put it bluntly, inhumane. His central case in point is the scandal of the late 1990s and early 2000s at Liverpool's Alder Hey Children's Hospital. Tissues and body parts of deceased children had been kept without parents' consent, and when this fact came to light, some parts were returned but others were not. The point which evidently disturbs Banner the most is not just that hospital officials would claim the right to keep children's body parts against the wishes of parents, but that, during official inquiries, they expressed bafflement that parents felt the way they did. Such a failure to understand parents' deep ethical commitments towards their late children, Banner writes, points to the need for moral theology to engage closely with anthropology, and specifically ethnography, in order to learn how humans really think about (and act within and towards) processes of conceiving, birthing, suffering, dying, and burying.

${ }^{4}$ In the second telling of the story in Genesis 2, God does not create humanity in the divine image out of nothingness but out of "the dust of the ground" (Genesis 2:7). For some Christians, 2 Corinthians 5:17 signifies a "new creation" of humanity, although this newness is predicated on surpassing oldness rather than emerging from nothing.

${ }^{5}$ He received his doctorate from the Augustana Divinity School in Neuendettelsau, Germany, in 2000, and has held visiting fellowships at University of California-Berkeley, Union Theological Seminary, Vancouver School of Theology, and the University of Winnipeg. He has taught at the Pacific Theological College in Suva, and in Auckland at both the University of Auckland's School of Theology and Trinity Methodist Theological College. He also served for six years as a pastor in Henderson, west Auckland, in a Methodist Church rather than a Congregationalist one.

${ }^{6}$ For his Bachelor's thesis he used his full name, Ama'amalele Tofaeono Siolo II, but in later works he has gone by the shorter form Ama'amalele Tofaeono.

${ }^{7}$ Compare Valeri's (1989:240) discussion of the "exemplar," a model for repetition that can never actually be repeated: "For, on the one hand, an exemplar demands to be imitated, reproduced and thus ultimately, substituted; but on the other hand, it claims that it cannot truly be reproduced and thus ever be displaced. What keeps its authority is precisely that it creates both a desire to be like it, to take its place, and a sense that it is impossible to do so" (Valeri 1989:240; see also Bandak and Højer 2015).

${ }^{8}$ These verses mention, respectively: "a jewel of gold in a swine's snout" (compared to "a fair woman...without discretion"); people "which eat swine's flesh, and broth of abominable things is in their vessels"; and one who "offereth an oblation, as if he offered swine's blood." 